Homelski Państwowy Uniwersytet

im. Francyska Skaryny

https://orcid.org/0000-0001-8644-6406

\title{
Инварианты художественной репрезентации истории Алесем Аркушам: контекст современной белорусской прозы
}

Историческая тематика в белорусской литературе остается востребованной на протяжении последних десятилетий и популярность ее среди читателей неизменно растет. При этом в прозе современных белорусских писателей как старшего, так и самого молодого поколений появляется ряд универсальных мотивов и образов, с помощью которых авторы обращаются к актуальным проблемам памяти, трансляции и преемственности культурных установок, возрастает потребность в современном переосмысления ключевых моментов истории, инвариантов в подходах к художественному отображению национального прошлого. Можно с полным основанием утверждать, что в своих романах полоцкий писатель Алесь Аркуш сконцентрировал основные мотивы, клише и инварианты восприятия и трактовки национального прошлого, свойственные белорусским авторам последних десятилетий.

1) Тема утерянных реликвий или клада.

Многие критики и читатели отмечают одержимость белорусских писателей темой старинных сокровищ: Ну колькі ўжо ёсщь беларускіх твораў, дзе так иі інакш шукаючь нейкі артэфакт, звязаны з велічнай гісторылй Вялікага Княства (...) Гэта ўжо стала банальнасцю. I тое, што артэфакт у выніку робіииа недаступным $i$ вабнылм - не спойлер, а штамп. Увогуле, здаеича, беларусы памяшаныля на тэмах скарбаў. I абавязковых зваротаў да мінулага ${ }^{1}$. Однако подобная тен-

1 K. Курчанкова, Рэцэнзія на кнігу: Алесь Аркуш, Сядзіба, [online], https:// www.livelib.ru/review/958199-syadziba-ales-arkush, [доступ: 12.02.2019]. 
денция напрямую отражает особенности национальной истории, которая многие годы и даже столетия - в зависимости от меняющихся общественных условий - замалчивалась, открыто уничтожалась, фальсифицировалась, либо навсегда исчезала в закрытых архивах. Архитектурные и художественные шедевры разрушались или вывозились, и все эти недостижимые сокровища являются марамі начыянальнай інтэлігенцыі аб вяртанні $і$ засваенні духойных набыткаў народу, скрадзеньıx, здраджаньх, занядбаньих $x^{2}$. Образ клада - похороненного прошлого - становится ключом к пониманию себя, своей идентичности, неотъемлемой частью культурного кода, символом того, что мы потеряли и никогда не перестанем искать.

Недоступным клад остается по вполне простой причине отсутствия достойных наследников и условий для принятия правды о себе. После краткой экскурсии вход в полоцкие лабиринты и легендарные летописи всегда скрывается (Л. Рублевская, А. Аркуш), кубок Батория/ корону Витовта забирают на хранение воды моря или реки. Легенде не время вернуться, так как мы физически не можем ее защитить: $A$ mbl хачеў бы, каб кубак знайшоў сьледчь Цісовіч? (...) Дь не, якраз гэта быу бы вельмі кепскі фінал. Бо кубак далей абавязкова спльй бы ў расейскія, можа крамлёусккія, сховы, як $і$ сотні іншых нашых рәліквіяў․․

Поэтому тема кладов неизменно оказывается связана с ощущением необратимой утраты (Мажиловский, Рублевская, Аркуш и др): Большасьць каштоўных археалягічных знаходак (...) апынуліся у фондах музэяў Масквы $і$ Ленінграда. Вярнуць іх законным гаспадарам ужо было немагчьлма

На почетное место в национальном музее или достойный памятник не может рассчитывать даже всемирно признанный герой или художественный гений: На жаль, зьезьдзічь у музэй-сядзібу Івана Хруикага можна будзе яшчэ ня хутка. Пакуль ва йладаў хапае грошай толькі на адбудову сядзібы Ільлі Рэпіна ${ }^{5}$.

Поэтому и не даются заклятые сокровища в руки ленивых и апатичных потомков, которые не задают даже очевидных вопросов, и в оценке которых звучит вполне заслуженная авторская ирония: А табе не падаециа дзіўным, што не захаваліся зьвесткі пра месиа

2 С. Шыдлойскі, Кніга з Полачка: да традыцыі полацкай метагістарычнай прозыl, "Маладосць" 2017, № 5, с. 142.

3 А. Аркуш, Сядзіба: раман, Полацак 2017, с. 129.

4 А. Аркуш, Захоп Беларусі марсіянамі: раман, Полацк 2016, с. 39.

5 Там же, с. 69 
пахаваньня такой значнай асобь ў легендах $і$ паданьнях. - Хочаш сказащь, што БัУсяслаў не памёр, а жьве па сёньня? (...) - Хачу сказаць, што з полацкай гісторьяй зусім кепска, калі да сёньня невядомьяя maкiя рэчьв 6 .

Сама неуловимость придает сокровищу ореол мистики и легендарности, к чему и стремится большинство авторов: Часам легенда пра скарб больш істотная за сам скарб. Скарб знайшлі, скарьсталі - $i$ усё. А легенда жьве стагодзьдзямі7. И если человек несвободен и может в любой момент лишиться всего, а материальное наследие превратиться в руины или тюрьму - мысль, идея - единственное, что ему остаётся: I што ты можаш пакінуць свайму гораду? Толькі верш. Толькі міт 8 .

2) Артефакт в центре внимания наделяется символикой Святого Грааля белорусской истории (недаром это кубок у Аркуша, Рублевской) либо апеллирует к образу божественной / королевской власти как символу государственности (корона Витовта). И в этом проявляется квазирелигиозный характер патриотизма белорусских героев, где утрата святыни становится и следствием, и причиной упадка национального: згубіўшь рэліквію, род Зяновічаў пачаў занепадащь, гэтаксама як $i$ яго Бацькаўшчьна ${ }^{9}$. Отсюда сближение понятий патриотизма и святости (Дайнеко, Ипатова, Ковтун, св. Торвальд у Аркуша), внимание к могилам и местам захоронения героев, в отношении которых употребляется понятие «пантеон»: не захаваўся ні пантэон полацкіx князёу ${ }^{10}$, солярная символика в описании положительных персонажей: Постаць яго празрыстая, як з туману. I толькі на грудзях штосьиі зырка адбівае промні сониа ${ }^{11}$.

3) В раскрытии темы национальной истории писатели последовательно воплощают принцип «В начале было Слово», который реализуется на нескольких уровнях.

Во-первых, самым ценным кладом неизменно оказываются не вещественные сокровища, а текст. Герои белорусских писателей неизменно делают выбор в пользу знаний и приоритетом для них всегда является поиск архивов, тайных библиотек и документов, Бо часам

\footnotetext{
6 А. Аркуш, Сядзіба..., с. 84.

7 А. Аркуш, Спадчьна: раман, Полацак 2018, с. 91.

8 Там же, с. 91.

9 А. Аркуш, Сядзіба.., с. 73.

10 Там же, с. 84.

11 Там же, с. 37.
} 
веды даражэй за любыя скарбы $1^{12}$. Написанное слово - единственно гарантированная форма земного бессмертия (Тут бый Іван Шагойка ${ }^{13}$, каллиграфическим почерком пишет на деревянном бортике фонтана герой Аркуша). Текст - материальное выражение памяти, сгущение времени и эпохи, поэтому самым ценным предметом в кладе из романа Аркуша «Спадчына» становится старая перьевая ручка, галоўная nрылада праџьь $i$ зброя ${ }^{14}$, поэтому другой его герой Алесь Дударь найбольш узрадаваўся б, напрыклад, нейкім невядомым рукапісам иі кнігам ${ }^{15}$, што самьм старанным чьинам хаваючь у архіўных спэцсховах. Beдbl $і$ памячь ${ }^{16}$, этот скарб неачэнньи ${ }^{17}$ и единственный, которого даже репрессии не смогли отнять у героев белорусской прозы.

Во-вторых, творческое слово автора делает его демиургом, творцом своей версии исторического мифа, позволяет домыслить, восстановить недостающие кусочки исторической мозаики с уверенностью, что этот творческий импульс имеет силу воплотить созданный образ, концепцию в жизнь: Я танчу ў памячь пра Паэта, які аднойчы прачытаў мне вери $і$ даказаў: паэзія здольная ўпльвачь на жьицёв, - утверждает В. Орлов; адзінкі (...) маглі рабіџь сапраўдныя иуды. Гэта калі напісанае ажывала і рабілася рэальнасьчю. Дакладней, яно рэальна ўлььвала на жыцьиё людзей ${ }^{19},-$ верят персонажи А. Аркуша.

И такая позиция обоснована, ведь любое действие начинается с мысли, и заложить плодотворную, продуктивную идею - это цель большинства героев: Але навошта выснова $і$ выбар, якія нічога ня могущь зьмяніць рэальна? (...) Спачатку была думка, затым было слова, потым нарадзілася ўсё астатняе. Адказ спадабаўся Крокве ${ }^{20}$.

И в таком случае творческая интуиция оказывается инструментом выявления исторической правды ничуть не худшим, чем конвенциональные методы исследования. Преобладает ощущение, что мир идей действительно может породить мир вещей. Так происходит с героем «Спадчыны», который выстраивает гипотезу о жизни И. Шагойко, только чтобы потом получить документальное подтверждение ее пра-

12 А. Аркуш, 3axon..., с. 47.

13 А. Аркуш, Спадчьна..., с. 129.

14 Там же, с. 140

15 А. Аркуш, 3axon..., с. 47.

16 Там же, с. 97.

17 А. Аркуш, Палімпсэст: раман, Мінск 2012, с. 61.

18 У. Арлоў, Танцы над горадам, “Дзеяслоў” 2016, № 79, с. 44.

19 А. Аркуш, Зaxon..., с. 30.

20 Там же, с. 78. 
вильности: Аказваеича, усё тое, што мь йяўлялі сабе, хутчэй нават фантазіравалі, - праўда ${ }^{21}$.

И здесь как раз очень важным оказывается акцент не только на сухую фактологическую достоверность, но на ощущения от конкретного исторического периода, внимание не на факты и хронологию, а именно на атмосферу, впечатления от описываемых событий - отличительная черта в изображении конкретной эпохи таких писателей, как Аркуш, Рублевская, В. Орлов (в поздних произведениях), которые прежде всего ориентируются на создание «имиджа» страны. И только реалистических средств изображения в таком случае оказывается недостаточно.

4) Элементы магического реализма, фантастики (или метафизики, как предпочитает ее называть А. Аркуш), манипуляции с временем, пересоздание реальности - необходимые инструменты для обращения к сложным и не до конца разрешенным проблемным моментам национальной истории, трансляции своего видения и, прежде всего, желаемого эмоционального отклика на представленную концепцию национальной идентичности.

С. Шидловский назвал полоцкую литературу метаисторической, отмечая первостепенное значение воображения в художественном отображении прошлого: Полачкім аўтарам-літаратарам прыходзічча кампенсаваць брак гістарычных крыніи павышанай міфатворчай актьйнасию22. С помощью «міфапаэтычнага наратыву» автор интуитивно может восполнить картину реальности. Вполне в согласии с культурологической концепцией Д. Андреева, например, герои Аркуша надеются заполнить пустоты национальной истории, проникнуть в некий невидимый параллельный мир исторического знания: ёсьиь нейкая прастора думак ${ }^{23}$. Однако на настоящий момент подобное мифотворчество не является чертой исключительно полоцкой прозы, но универсальным инструментом большинства писателей, так или иначе затрагивающих тему национальной памяти и национального прошлого. Насамрэч наша жьцьцё пераважна дзеециа ў нашым уяйленьні, нашых марах, нашых снах. Калі думка чалавека, як сьцьвярджаюиь навукоўщьи, рэч матэрыяльная, дык чьлм тадыь розьнічиа рэальнасьць ад выдумленага?24

21 А. Аркуш, Спадчьна..., с. 147.

22 С. Шыдлоўскі, Кніга.., с. 141.

23 А. Аркуш, Спадчьна..., с. 143.

24 А. Аркуш, Палімпсэст.., с. 101. 
Прозрения, видения и беседы с призраками, сны - все это инструменты диалога, познания и трансофрмации действительности.

5) Миф, как справедливо отмечает С. Шидловский, это и авторские права на кусочек прошлого, ответ на многочисленные примеры "украденной истории". И одновременно - способ обессмертить свою страну, культуру, народ: Можна зруйнаващь магіль, знішчьиь кургань, ператварыць у друз храмь, замкі $i$ палащь, але немагчьма зьнішчьиь легенд $y^{25}$.

6) Творчество большинства писателей старшего поколения отражает неизжитую травму советского периода и кризисного последнего десятилетия XX века.

Нереализованные надежды, кризисные предапокалиптические ощущения страха, которые многие авторы вынесли сначала из советского прошлого, а затем из девяностых, выражаются и в декадентском восприятии города, и в странной нелюбви и даже презрении к джинсовой одежде, которую можно проследить от ранних романов Л. Рублевской до «Каларадскай пушчы» С. Квятковского. Раней мне здавалася,

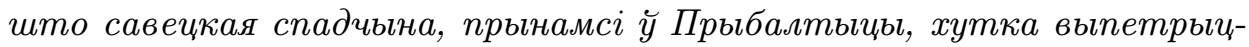
иа. Але дзе там! Гэтая спадчьна так уелася ў скуру, што немагчьма яе пазбавіииа ${ }^{26}$, - разочарованно отмечает герой А. Аркуша.

Ощущение деградации, утраты не только исторического наследия, но и величия, благородства, которая объединяет всех этих писателей, проявляется в постоянном внимании к шляхетскости и аристократизму (не только как социальному явлению, но как художественному выражению внутреннего благородства). Не в последнюю очередь благодаря созданию «высокого» национального мифа творчество В. Короткевича становится эталоном описания национальной истории как для авторов, так и для их героев: Hy, па-першае, пра нашую беларускую аісторью, $i$ ня толькі сялянскую 27.

Данная особенность выражается не только в происхождении, но и в выборе имен героев, вдохновением для которых становятся старинные гербы и фамилии (Рублевская, Климкович, Адамчик и др.). Шляхетским, созидательным в чем-то «царским» является по этимологии на первый взгляд простое имя «Василь Кроква» героя А. Аркуша.

Отречение от культуры аристократизма - признак вырождения: Полацак выглядаў так, нібыта былога шляхиіиа апранулі ў нейкае

\footnotetext{
25 А. Аркуш, Сядзіба.., с. 129.

26 А. Аркуш, Спадчына..., с. 53.

27 Там же, с. 142.
} 
рызьзё - у абліччы адчувалася былая веліч, але «вопратка» была жахлівая. Змрочнае ўражаньне ўзмачняла гарадзкая тапаніміка: усе гэтыля звыродлівыя назвы вуліи - Савецкая, Фрунзэ, Леніна, Камуністьиная, Карла Маркса, Войкава. I гэта ў самьлм гістарычныл иэнтры горадара

Близкое понятие индивидуализма как признак свободы неизменно противопоставляется безликой массе. Единомышленники вынуждены скрывать свою способность независимо мыслить от подозрительного внимания общества: Сам па сабе індыьвідуум зьнік як нетутэйшая форма жыцьия ${ }^{29}$. Возможно, в этом частично корни стремления к элитарности и герметичности (что начинает восприниматься как одно и то же) части белорусских литераторов. Первые романы А. Аркуша, например, написаны с расчётом на достаточно узкий круг людей: Большасць маіх раманаў досыиь герметычныля. Напрыклад, раман "Мясцовы час", (...) па-мойму, не будзе зразумель шырокому колу иьmачой ${ }^{30}$. Такой же тип автора воплощает его герой Василь Кроква: нiколі не арыентаваусся на нейкія моды, запатрабаваньні выдаўцоў або на патрэбу замежнага чытача. Ягоныя раманы былі гермэтычныя i скіраваныя выключна на беларускую аўдыторыю ${ }^{31}$.

Еще одно наследие прошлого - романтизация и облагораживание страданий. Герой-жертва - частый тип в произведениях Дайнеко, Ипатовой, Рублевской. Достаток и благополучие видятся чем-то мещанским и недостойным, переходят в процесс осуждения общества потребления, что несколько удивительно, так как это самое общество и влиятельный средний класс так и не успели полноценно сформироваться: ... у крамах зьявілася шмат розных прадуктаў. Потым людзі развучьліся рабіць сьвятыл і ствараць рытуальз ${ }^{32}$.

Разумеется, вышеперечисленные черты не исчерпывают всей специфики художественного отображения темы исторического прошлого в белорусской прозе. Присутствует общее стремление найти исторические связи с другими, более древними культурами и цивилизациями (скандинавской для Аркуша, римской для Рублевской или Дайнеко)

28 А. Аркуш, Мясцовы час: раман, Полацк 2014, с. 14.

29 А. Аркуш, Палімпсэст..., с. 114.

30 С. Дэдэрка, Алесь Аркуш свой пяты раман прьссвяиіў Спадчыне, [online], https://budzma.by/news/alyes-arkush-svoy-pyaty-raman-prysvyaciw-spadchynye.html, [доступ: 07.02.2020].

31 А. Аркуш, 3axon..., с. 9.

32 А. Аркуш, Спадчьна.., с. 116. 
как способ легитимизации собственной государственности, обязательное акцентирование языковой проблемы: Для Дудара не было ніякага іншага варыянту будучыні роднай Беларусі, як толькі ў разьвічьиі $i$ пашьрэньні роднай мовьз ${ }^{33}$. Склонность вставлять исторические отсылки в самые невинные реплики персонажей. Нібыта з Грунвальдзкай бimвы вярнуўся, - описывает потрепанного пса героиня "Сядзібы" 34. Универсальна увлеченность как авторов, так и их героев творчеством Вацлава Ластовского и Владимира Короткевича вплоть до прямых цитат и заимствования имен героев: Кроква любіў Ластоўскага. А ягоную аповесьиь «Лябірьнть» лічьюу сваёй настольнай кнігай ${ }^{35}$.

Можно заключить, что отображение исторической темы белорусскими авторами среднего и старшего поколения строится на парадоксах: борьба с одиночеством и одновременно упоение своей непонятостью и исключительностью, отвержение мировоззренческого наследия репрессивной кризисной эпохи и одновременная романтизация страданий, признание нежизнеспособности деревни в современном обществе и видение города как некоего потустороннего мертвого пространства. Создается концепция не реального, но идеального прошлого, «золотого века» аристократизма духа, ведется постоянный ностальгический поиск себя, явно ощущается стремление возродить возвышенное творческое, мифологизированное ощущение прошлого. Все это ведет к сплаву романтических (новый взгляд на привычные вещи, акцент на готические элементы, идеализацию прошлого, желание показать чудесное в обыденном, населив его в том числе природными духами и отголосками фольклорных верований), модернистских (экспрессионизм и глубокий внутренний психологизм, слияние сна и реальности) и постмодернистских элементов (магический реализм, фрагментация и стилистический минимализм, пародийность и пастиш, элементы метапрозы, выраженная интертекстуальность и др.).

\section{I T E R A T UR A}

Arkuš A., Mâscovy čas: raman, Polack 2014 [Аркуш А., Мясцовьь час: раман, Полацк 2014].

Arkuš A., Palimpsest: raman, Mìnsk 2012 [Аркуш А., Палімпсэст: раман, Мінск 2012].

\footnotetext{
33 А. Аркуш, 3axon..., с. 6.

34 А. Аркуш, Сядзіба.., с. 92.

35 А. Аркуш, 3axon..., с. 13.
} 


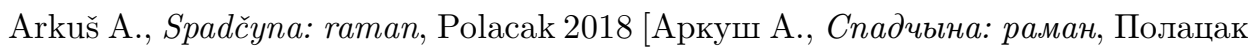
2018].

Arkuš A., Spadčyna: raman, Polacak 2018 [Аркуш А., Сядзіба: раман, Полацак 2017].

Arkuš A., Zahop Belarusi marsiânami: raman, Polack 2016 [Аркуш А., Зaxon Беларусі марсіянамі: раман, Полацк 2016].

Arloǔ U., Tancy nad goradam, "Dzeâsloŭ" 2016, № 79 [Арлоў У., Таниьь над горадам, “Дзеяслочу" 2016, № 79].

Dèdèrka S., Ales' Arkuš svoj pâty raman prysvâciǔ Spadčyne, [online], https://budz ma.by/news/alyes-arkush-svoy-pyaty-raman-prysvyaciw-spadchynye.html, [dostup: 07.02.2020] [Дэдэрка С., Алесь Аркуш свой пяты раман прыссвяиіў Cпадчьъне, [online], https://budzma.by/news/alyes-arkush-svoy-pyatyraman-prysvyaciw-spadchynye.html, [доступ: 07.02.2020].

Kìrkevìc A., Kamu i navošta varta èytac' "Tancy nad goradam" Arlova, [online], https://budzma.by/news/kamu-i-navoshta-varta-chytac-tancy-nad-horadam -arlova.html, [dostup: 12.01.2020] [Кіркевіч А., Каму і навошта варта чьытаць "Танцьь над горадам" Арлова, [online], https://budzma.by/news/ kamu-i-navoshta-varta-chytac-tancy-nad-horadam-arlova.html, [доступ: 12. 01.2020].

Kurčankova K., Rècènziâ naknìgu: Ales' Arkuš "Sâdziba", [online], https://www. livelib.ru/review/958199-syadziba-ales-arkush, [dostup: 12.02.2019] [Kypчанкова К., Рэиэнзія на кнігу: Алесь Аркуш “Сядзіба", [online], https:// www.livelib.ru/review/958199-syadziba-ales-arkush, [доступ: 12.02.2019].

Šydloǔskì S., Kniga z Polacka: da tradycyi polackaj metagistaryčnaj prozy, "Maladosc"' 2017, № 5 [Шыдлоўскі С., Кніга з Полацка: да традыцыі полачкай метагістарычнай прозы, "Маладосць" 2017, № 5].

\section{P E 3 Ю $\mathrm{M}$}

\section{ИНВАРИНТЫ ХУДОЖЕСТВЕННОЙ РЕПРЕЗЕНТАЦИИ ИСТОРИИ АЛЕСЕМ АРКУЩАМ: КОНТЕКСТ СОВРЕМЕННОЙ БЕЛОРУССКОЙ ПРОЗЫ}

Вопросы культурного наследия и вопросы исторической правды были ключевыми в белорусской литературе на протяжении последних десяти лет, более того, их популярность и актуальность как для авторов, так и для читателей постоянно растет. Вместе с этим часто можно выделить множество повторяющихся мотивов и образов, появившихся в художественной литературе тех современных белорусских писателей, которые обращаются к критическому переосмыслению истории страны. С помощью таких мотивов авторы рассматривают проблемы исторической памяти, идентичности и культурной преемственности. В статье представлены «инварианты» литературного представле- 
ния истории, часто определяемого исторической травмой советских и постсоветских времен.

Ключевые слова: современная белорусская литература, миф, тема, культурная преемственность, историческая травма.

\section{S T R E S Z C Z E N I E}

\section{INWARIANTY LITERACKIEJ REPREZENTACJI HISTORII NA PRZYKEADZIE TWÓRCZOŚCI A. ARKUSZA}

Pytania dotyczące kulturalnej spuścizny i kwestii prawdy historycznej były kluczowe w literaturze białoruskiej w ciągu ostatnich dziesięciu lat. Ich popularność i znaczenie zarówno dla autorów, jak i czytelników stale rośnie. Jednocześnie można wyróżnić wiele powtarzających się motywów i obrazów, które pojawiły się w utworach tych współczesnych białoruskich pisarzy, którzy zwracają się w kierunku krytycznej reinterpretacji historii kraju. Za pomocą takich motywów autorzy omawiajac pilne problemy historycznej pamięci i ciągłości kulturowej.

Artykuł przedstawia «inwarianty» literackiej reprezentacji historii, często determinowanej historyczną traumą czasów radzieckich i poradzieckich.

Słowa kluczowe: współczesna literatura białoruska, mit, motyw, ciągłość kulturowa, trauma historyczna.

\section{S U M M A R Y}

\section{LITERARY INVARIANTS IN THE REPRESENTATION OF HISTORY IN THE WORKS BY A. ARKUSH}

The questions of historical past and cultural heritage have been central in Belarusian literature over the past decades. Moreover, their importance for both authors and readers is steadily growing. At the same time, a number of recurrent motifs and images, with the help of which the authors address the urgent problems of historical memory, identity and cultural continuity have resurfaced in the fiction of contemporary Belarusian writers, who are addressing the need for a modern reinterpretation of key moments in national history. The article aims to single out "invariant" approaches to the literary representation of the national past often determined by the historical trauma of the Soviet and post-Soviet periods.

Key words: contemporary Belarusian literature, myth, motive, cultural continuity, historical trauma. 